\section{An Artist's Sketchbook: the former altarpiece of Goa Cathedral (India) attributed to the painter Garcia Fernandes - iconographic and stylistic influences and underdrawing study}

\section{O caderno de esboços de um artista: 0 antigo retábulo da Sé de Goa (India) atribuído ao pintor Garcia Fernandes - influências iconográficas, estilísticas e estudo do desenho subjacente}

\section{VANESSA ANTUNES $S^{1,2} *$ (1) VITOR SERRÃO ${ }^{1}$ ANTÓNIO CANDEIAS ${ }^{3,4}$ [ JOSÉ MIRÃO ${ }^{3}$ SARA VALADAS 3 \\ MARIA LUÍSA CARVALHO $^{2}$}

1. ARTIS-Instituto História da Arte da Faculdade de Letras da Universidade de Lisboa (ARTISFLUL), Alameda da Universidade, 1600-214 Lisboa, Portugal. 2. LIBPhys-UNL, Laboratório de Instrumentação, Engenharia Biomédica e Física da Radiação, Departamento de Física, Faculdade de Ciências e Tecnologia, Universidade Nova de Lisboa, 2829-516, Caparica, Portugal.

3. Laboratório HERCULES, Escola de Ciências e Tecnologia, Universidade de Évora, Largo Marquês de Marialva 8, 7000-676 Évora, Portugal.

4. Laboratório José de Figueiredo, Direcção-Geral do Património Cultural (LJF-DGPC), Rua das Janelas Verdes 37, 1249-018 Lisboa, Portugal.

*vanessahantunes@gmail.com

\section{KEYWORDS}

Garcia Fernandes Portuguese painting Goa Cathedral Underdrawing Infrared reflectography Iconography

\section{PALAVRAS-CHAVE}

Garcia Fernandes

Pintura portuguesa

Sé de Goa

Desenho subjacente

Reflectografia de infravermelho

Iconografia 


\section{Introduction}

Garcia Fernandes was active in Lisbon between 1514 and 1565. He was a pupil at the Royal Painting Workshop of Jorge Afonso (Lisbon), his father in law, who had him in high regard. He collaborated in the works of the Court of Relation, under the leadership of Francisco Henriques (151819), worked in Lamego and Ferreirim with Cristóvão de Figueiredo and Gregório Lopes (1533-34) and, among many other works, painted for India at c. 1538. Garcia Fernandes style is influenced by German and Flemish models. The art historian Luís Reis-Santos (1954) identified the paintings of the sacristy of the Sé of Goa as being painted by Garcia Fernandes, as result of a possible request of the King of Portugal. These paintings are very remarkable works of art and may be one of the oldest paintings of European origin that exist today in the entire Indian territory [1, 2, p. 136-139, 3, 4, p. 212-215].

The first altarpiece of Goa Cathedral was dedicated to St. Catherine of Alexandria, attributed to Garcia Fernandes and painted c. 1538 . The altarpiece is nowadays in the sacristy of Goa Cathedral and is composed by seven remaining paintings under the following themes and current display: St. Catherine survival of death by a spiked wheel; The Empress's visit and conversion; St. Catherine imprisonment by the Emperor; St. Catherine represented as Princess of Alexandria; The Beheading of St. Catherine of Alexandria; The debate with pagan scholars; The deposition of St Catherine by angels on Mount Sinai (Figure 1). Due to changes in style and taste, the altarpiece made by Garcia Fernandes was replaced with a new one: in 1632 it was made the drawing and carving of the
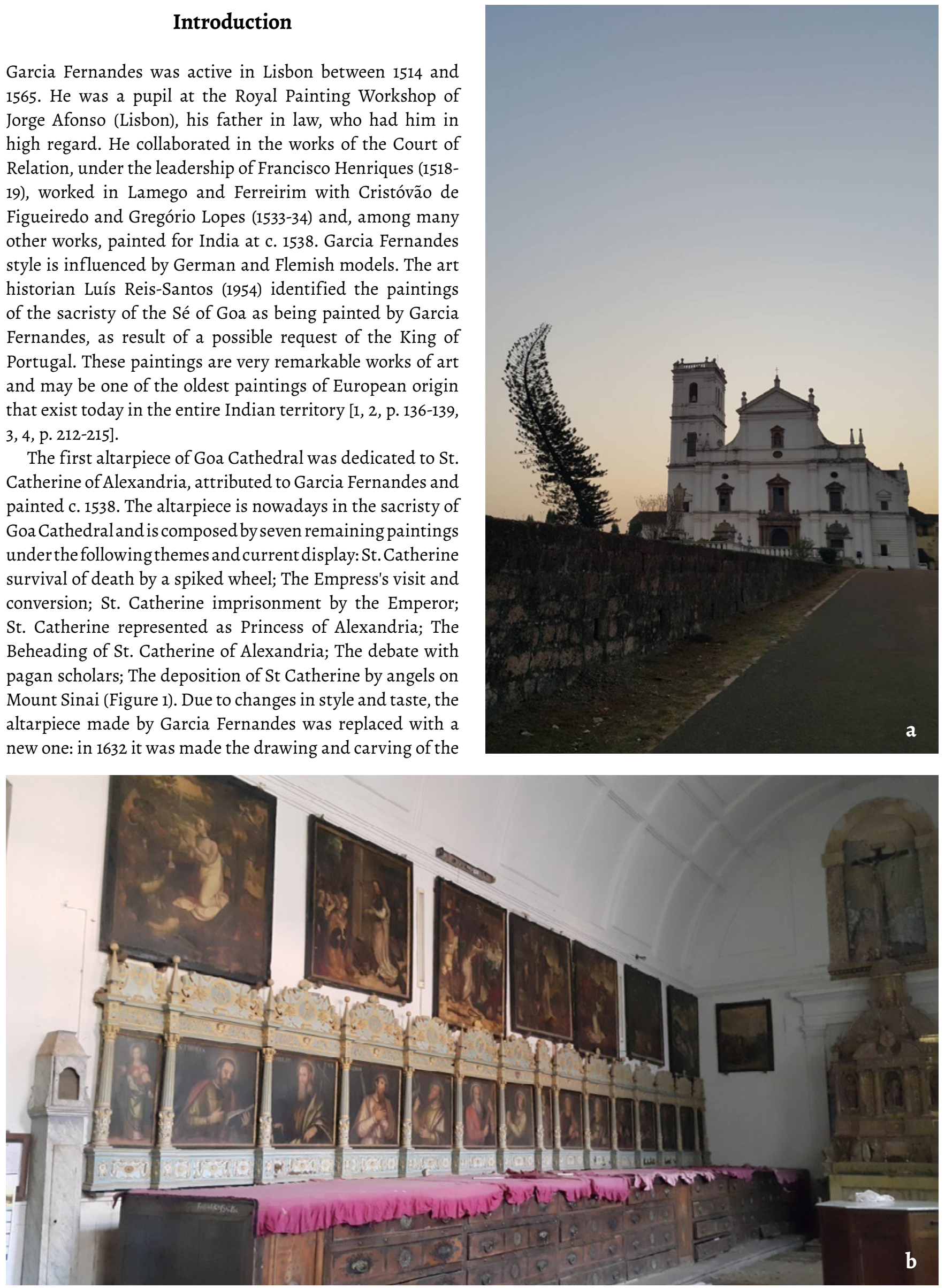

Figure 1. a) Goa Cathedral, dedicated to St Catherine of Alexandria. b) Former altarpiece, nowadays in the sacristy of Goa Cathedral, attributed to the painter Garcia Fernandes and painted c. 1538. 
new gilded altarpiece which was finished in 1634. The new altarpiece of the main altar of the Goa Cathedral was made on the orders of the Viceroy Count of Linhares. This gilded altarpiece, had "feature" of the architect Julius Simonis and was executed in the workshop of the sculptor master Babuxa, followed the compositional models of the previous altarpiece, a proof of its importance in Goa. The altarpiece copies the paintings under the following themes: The debate with pagan scholars; St. Catherine survival of death by a spiked wheel; The Beheading of St. Catherine of Alexandria; The deposition of St Catherine by angels on Mount Sinai; St. Catherine represented as Princess of Alexandria.

Goa Cathedral former altarpiece is in urgent need of intervention [5]. Part of the underdrawing and painting are in process of disappearing due to the high level of ground layer losses and degradation and lack of adherence to the wooden support [5-6]. A plan for its conservation was prepared but the financing was still not possible. The detachment of the ground and painting layers from the support caused the flaking of the paintings. In order to cover the great extension of lacks former overpaintings were made. These overpaintings, visible by naked eye and under UV light, show a great thickness with very plastered materials, damaging the original painting. Main shape references of some paintings were completely lost, such as the face of St. Catherine represented as the Princess of Alexandria, in need of urgent conservation and restoration; current thermo hygrometric conditions and external biological contamination contribute also to the degradation of the paintings [5-6].

In this paper, Goa Cathedral former altarpiece underdrawing is studied and is compared to other works of Garcia Fernandes, such as the Triptych of Calvário from Vila Viçosa Palace, of c. 1536, the altarpiece of the Holy Trinity from Mosteiro da Santíssima Trindade (Museu Nacional de Arte Antiga (MNAA), 35, 38, 39, 43, 379, 676, 680, 705 Pint), of 1537, the painting Saint Anthony Preaching to the Fishes (MNAA, inv. 1768 Pint), c. 1535-1540 and the painting Creation of Eve from Alfama (Portugal). Partnership works were also compared, such as Ferreirim altarpiece, 1533-34, the painting Death of the Virgin, c. 1530-40 (Museu Nacional Grão Vasco (MNGV), inv. 2168), the polyptych of S. Bartolomeu from Bartolomeu Joanes chapel, dating from 1537, Lisboa Cathedral, a former predella, nowadays in Museu Nacional Machado de Castro (MNMC) (inv. 2536; P526), painted c. 1525-1550 and a collaborative work in the paintings Adoration of the Magi and The birth of the Virgin, attributed to Garcia Fernandes, 1520-1530, from António Trindade Collection.

The aim of this study is to highlight a Master's working process and point out possible collaborations and tendencies at the level of the style, iconography and underdrawing adopted by Garcia Fernandes.

This research will be deepened to other technical and material levels of the paintings [7]. At this stage, we used direct observation of the works, combining iconographic sources and area examinations, namely Macro Photography, Infrared Photography (IRP) and Infrared Reflectography (IRR) [8]. These examinations allowed the study of the works through the analysis of the underdrawing, one of the phases resulting from the creative process, for the freedom of the artist to express itself "unseen" in a context marked by a certain rigidity of rules [9-11].

\section{Methods used for the study of the underdrawing}

\section{Macro Photography (MP)}

Details of the chromatic layers were captured with a mobile microscope 3 " LCD 8.5 Mega Pixels. Magnification is 20-500 x. The microscope has a Digital LCD with VGA, Micro SD card storage, and a Micro Capture Pro software. When performing MP the details focused were the areas where the underdrawing was visible by naked eye, in order to confirm IRR and IRP exams.

\section{Infrared Reflectography (IRR) and Infrared Photography (IRP)}

Examination by IR photography was obtained with a digital camera SONY DSC-F828, 7 Mega Pixels.

A high-resolution infrared reflectography camera (Osiris) with an InGaAs detector allowing a wavelength response from 900 to $1700 \mathrm{~nm}$, was used to perform Infrared reflectography. Osiris is equipped with a $16 \times 16$ tile system which enables an image size of $4096 \times 4096$ pixels. The camera is incorporated with a long-pass filter Schott RG850. Infrared wavelength is transmitted blocking undesired shorter wavelength until $850 \mathrm{~nm}$. Reflectograms recording respected a working distance (front of body camera to painting) of $125 \mathrm{~cm}$, and focus (front of body camera to the lens) of $28 \mathrm{~cm}$ and a $\mathrm{f} / 11$ aperture. Reflectograms were performed for $60 \times 60 \mathrm{~cm}^{2}$ painting area. Diffuse illumination at 1000 lux was brought by reflectors with 2 x 1000 W Tungsten Halogen VC -1000 Q Quartz Light. The final image is composed of several reflectograms.

Infrared Reflectography (900 to $1700 \mathrm{~nm}$ ) and Infrared Photography $(800 \mathrm{~nm})$ were used to detect carbonbased underdrawings by using different wavelengths. Both techniques were used in order to obtain a bigger quantity of information for comparison. These photos and reflectograms were captured on details of the paintings and, when needed, assembled in Photoshop CS5 with Photomerge tool. Adjusting levels and increase contrast were necessary in each reflectogram.

\section{Results and discussion}

Stylistic comparison between Garcia Fernandes paintings Stylistic similarities and the use of analogous models 

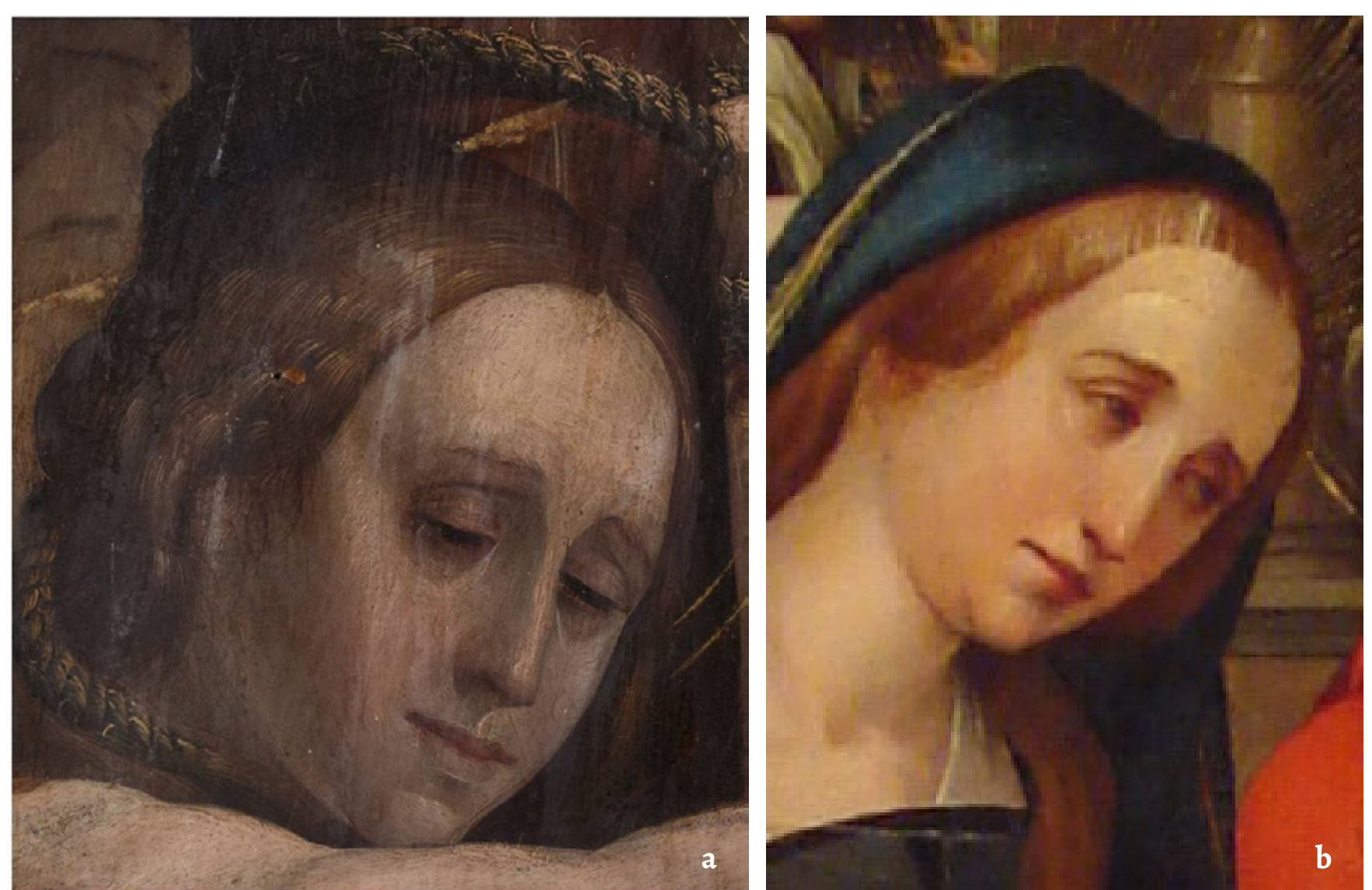

Figure 2. a) Detail of St. Catherine imprisonment by the Emperor, Goa Cathedral (Photo: Ian de Noronha, 2017). b) Presentation of Jesus in the Temple, Garcia Fernandes, 1538, MNAA, Lisbon, inverted image.

are found between the first altarpiece of Goa Cathedral attributed to Garcia Fernandes [6] and other works of the same painter in Portuguese territory [12-18]. It is the case of the Goan altarpiece, painting of St. Catherine survival of death by a spiked wheel with similar angels to the represented in Ascension of Christ from the altarpiece of the Holy Trinity painted by Garcia Fernandes in 1537 (MNAA), or the angel of the painting Annunciation, altarpiece of Bartolomeu Joanes, made by Garcia Fernandes in partnership with other painters, c. 1535-1540 (Lisbon Cathedral) [19-20]; the face of Saint John in the painting Testimony of Saint John the Baptist with the priests and Levites of Jerusalem, attributed to Garcia Fernandes, c. 1535-1540 (MNAA) when compared to the noble's face in the painting of The Beheading of St. Catherine of Alexandria, of Goa Cathedral; The Holy women and Saint Joseph's faces in the painting Presentation of Jesus in the Temple, made by Garcia Fernandes in 1538 (MNAA) under the same molds of the Saint's faces in the two paintings of Goan altarpiece, St. Catherine imprisonment by the Emperor and The Beheading of St. Catherine of Alexandria (Figure 2), or the detail of the crown helmet used in the Goan painting The Empress's visit and conversion used also in the painting The birth of the Virgin, attributed to Garcia Fernandes, c. 1520-1530 (António Trindade Collection). It is also possible to find similar formal composition between the painting Elevation of the body of Santa Catarina, attributed to Garcia
Fernandes, c. 1525-1550 (MNAA, Lisbon) and the painting under the same theme at Goa Cathedral and also to the same models used by his master, Jorge Afonso in Lisbon painting Workshop [12, 18, 21].

\section{Iconographic and graphic influences}

Iconographic and graphic influences by German, Flemish and Italian models are evident in Garcia Fernandes work. In the painting St. Catherine survival of death by a spiked wheel of Goa Cathedral it is possible to find influences of The Beheading of Saint Catherine of Alexandria, engraving made by Albrecht Dürer in 1498 [22], of the engraving made by Hans Schäufelein c. 1509-1510 under the same theme [23] showing similar hat in the male figure and inspired in the engraving's architectural background or of the engraving made by the netherlandish Master S, of c. 1500-1525, that displays a similar angel than those represented by Garcia Fernandes in the Goan painting [24].

Other engraving of The Martyrdom of St Catherine, made by the German Monogrammist IE, c. 1480-1500 [25], who was probably colleague or apprentice in Schongauer's workshop [26] displays a man figure to the left of the Emperor Maxentius standing in the same inverted position as the noble man in the painting of The Beheading of Saint Catherine of Alexandria, Goa Cathedral (Figure 3).

The most evident engraving relation to Goan former 

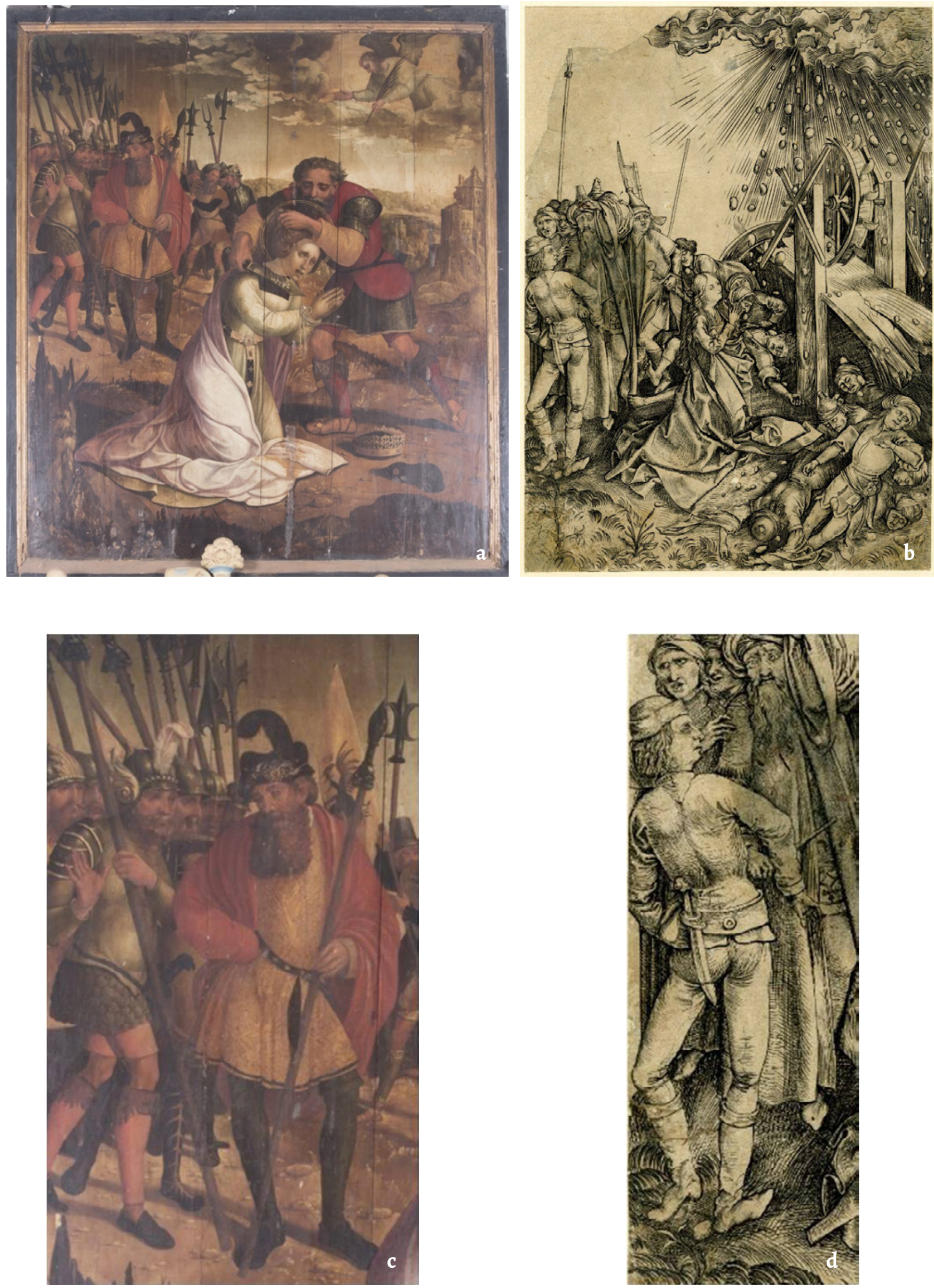

Figure 3. a) and c)The Beheading of St. Catherine of Alexandria Goa Cathedral (Photo: Ian de Noronha, 2017). b) and d) Print made by monogrammist IE, 14801500 (The trustees of the British Museum). 
altarpiece is the collection of Vita S. Catharinæ, Virg. et Martyris, Catharina virgo Ægyptia, Alexandriæ regio, genere nata, An. Christi circiter CCCVII. This collection displays a series of sixteen Flemish plates with the life of St Catherine after Adriaen Collaert, probably engraved by Adriaen or Jan II Collaert and published by Carel Collaert between 1613 and 1654. This series has a dedication to the Lectissimæ Virgini Catharinæ le Mire Soro from the flemish academic Aubert le Mire, which lived between 1573 and 1640 and wrote works in the fields of history and ecclesiastic history [27]. Since in the biography of this ecclesiastic it is not evidenced a trip to Goa [28] that could put him in contact with Garcia Fernandes altarpiece, the most probable is that it may have existed a former series of engravings under the same themes and graphic composition, copied in the 17th century by the Collaert family. Similarities in the location and position of the figures are found between the Goan former altarpiece and the following engravings: St Catherine disputing with fifty
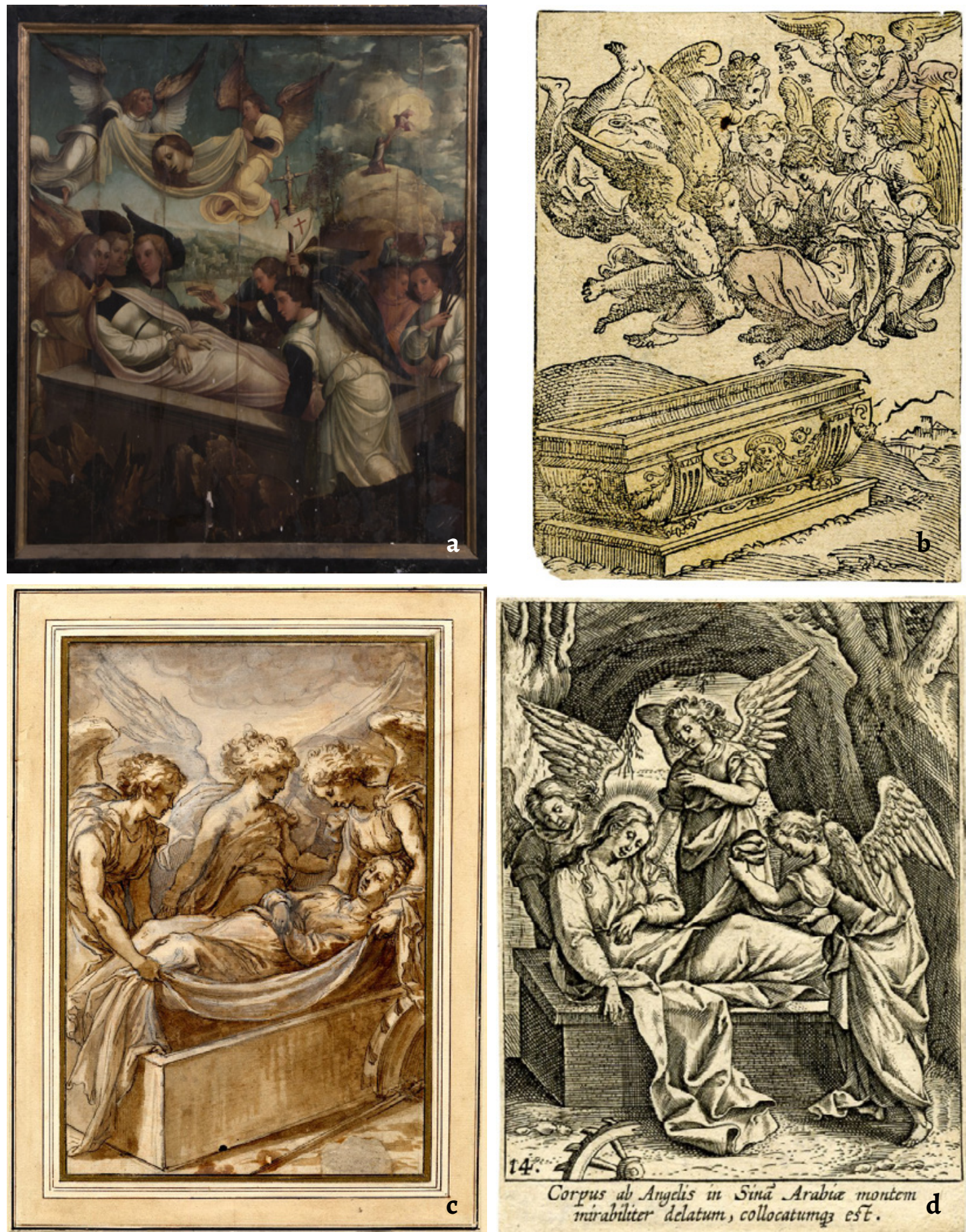

Figure 4. a) The deposition of St Catherine by angels on Mount Sinai, Goa Cathedral. b) La Vita di Caterina Vergine and Martire, made after Francesco Salviati and Giorgio Vasari, 1541 (The trustees of the British Museum). c) The Burial of St Catherine copied after Pompeo dell 'Aquila, c. 1511-1571 (The trustees of the British Museum). d) The deposition of St Catherine by angels on Mount Sinai, print made by Jan Collaert II(?), published by Carel Collaert after Adriaen Collaert, 1613-1654 (The trustees of the British Museum). 
philosophers (Plate 6) [29], St Catherine being tortured (Plate 8) [30], The queen and Porphyrius converted by St Catherine (Plate 9) [31], The beheading of the queen and Porphyrius (Plate 10) [32], The Life of St. Catherine of Alexandria (Plate 12) [33], The beheading of St Catherine (Plate 13), and The deposition of St Catherine by angels on Mount Sinai (Plate 14) [34]. In this last painting influence from other engravings can be found. It is the case of the engraving La Vita di Caterina Vergine and Martire [35], made after Francesco Salviati and Giorgio Vasari, in 1541, to the engraving of Deposizione di Santa Caterina d'Alessandria nel sepolcro [36], also Italian made after 1550, or to The Burial of St Catherine made after Pompeo dell'Aquila c. 1575, engraving made by Cornelis Cort and published by Lorenzo Vaccari [37].This theme can also be found in a drawing copied after Pompeo dell 'Aquila, c. 1511-1571 [38] or to a painting under the same theme made by Venetia school of the "Cinquecento" from the workshop of Jacopo and Domenico Robusti, known as Tintoretto [39], from the second half of the 16th century (Figure 4).

The central panel of the former altarpiece must have been St Catherine as a Martyr where similarities with Plate 1 [40] of the same Collaert series are evident. The saint is positioned at centre, holding her attributes, a book and a palm leaf, and a broken wheel stands behind her in a landscape, such as emperor Maxentius lying down at her feet. This engraving seem to be inspired also in former engravings of this saint made by Martin Schongauer c. 1469-1482 [41]. But this theme can also be compared to coeval Portuguese panel paintings such as the one in Museu Nacional do Azulejo, Madre de Deus Church, dated from the 16th century, to the Saint Catherine from the Monastery of Celas polyptych, made c. 15011525 by the Coimbra workshop painters Vicente Gil and Manuel Vicente, the St Catherine of Vasco Fernandes (MNAA deposited in MNGV), c. 1511-1515, or to the mural painting of Catarina de Alexandria signed by the painter Moraes in 1536 from the Church of Santo Isidoro, Marco de Canaveses. Goan former altarpiece can also be related to the Mystical Marriage of Santa Catarina, Santa Clara, Santo António and a Holy Saint, of c. 1570-1595, of unknown author (inv. 11703, MNAA) or to its pair, the Martyrdom of Saint Catherine of Alexandria (inv. 10974, MNAA) where formal similarities to the Goan painting under the same theme can be found, in a probable similar engraving inspiration used in different epochs.

Based in the Saint's hagiography it is possible to deduce the paintings distribution of the former altarpiece of Goa Cathedral, also confirmed by the numbering of Collaert plates and the 17th century carved altarpiece nowadays in the main chapel.

Other works assigned to this painter also have FlemishGerman influences. The painting Creation of Eve, attributed to Garcia Fernandes is inspired in the engraving of Wolgemut, as studied by Manuel Batoréo, but also in the engravings of book-illustrations such as the one made after Hans Holbein the Younger by Jan Swart van Groningen and published by Willem Vorsterman in 1528, Antwerp [42].

The Former Monastery of the Holy Trinity altarpiece is one of the most important altarpieces of Garcia Fernandes. The altarpiece is composed by 8 paintings, nowadays in MNAA. In the painting of The Transfiguration some resemblances with the engraving Transfiguratio Domini nostri Iesu Christi, book-illustration, made by Anonymous artist and engraved by Martin Bouillon, 1510-1519, are found [43]. The painting Ascension of Christ seems to have inspiration on an engraving of The Last Judgement made by Hans Baldung, 1505-1507 [44]. The painting of the Holy Trinity has inspiration on engravings made by Martin Schongauer such as Christ enthroned, 14781482 [45], or The Assumption of the Virgin, 1470-1480 [46].

\section{Technical characterization of the underdrawing of Goan altarpiece}

Due to the ageing of the painting layers and subsequent detachments it is possible to see in some parts of the paintings the underdrawing and the ground layer by naked eye (Figure 5).
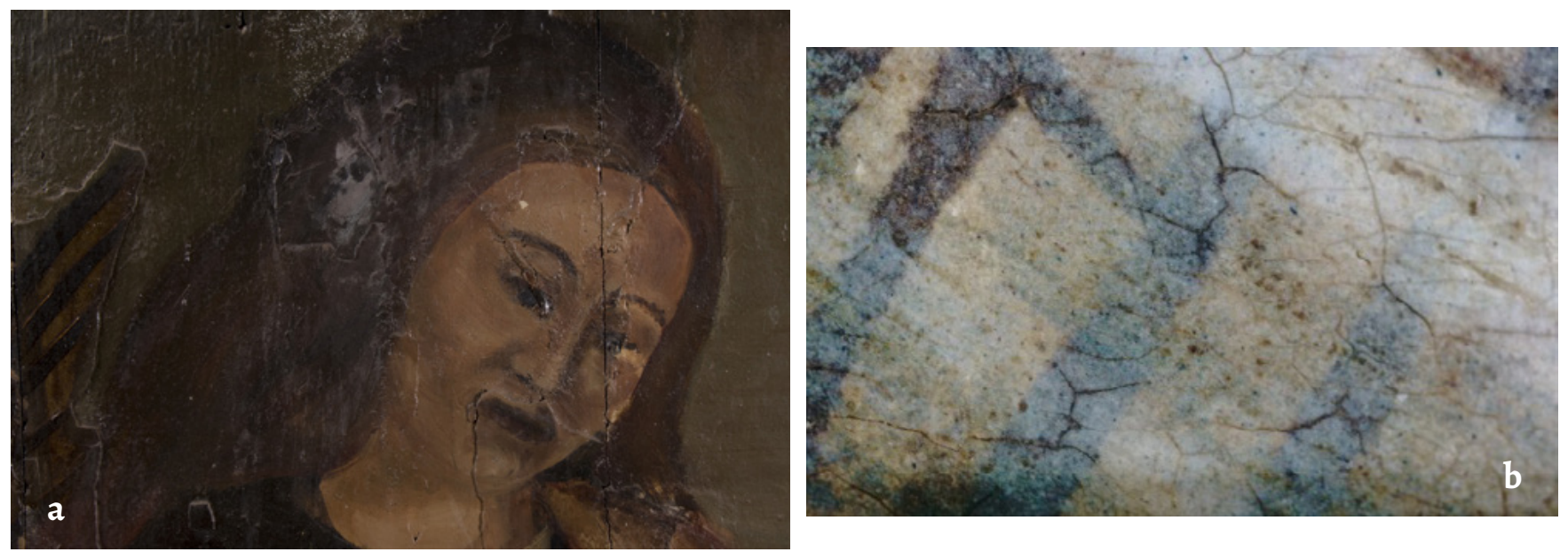

Figure 5. a) Detachment of ground layer from the support causing the flaking of the painting, showing also overpaintings. b) Transparency of painting layers, being possible to see the underdrawings and the ground layer. 
Infrared photography and reflectography allowed us to study in deep the underdrawing of Goa Cathedral former altarpiece. Distinct campaigns are revealed in all the seven panels in three stages. A first stage of geometric drawing (GD) characterized by the marking of the positioning of the figures and anatomical construction of the bodies and architecture with ruler and compass; a second stage of dry drawing (DD) made with charcoal to the outline of the figures or card transposition; a third stage of ink fluid carbon drawing (ID) characterized by variable width and intensity of the lines with a bigger density of the deposit drops at the end of each line, indicating the use of a fluid material [11, 47].This drawing, with bold appearance, was used to the correction of the $\mathrm{DD}$. An example of this drawing type can be seen in Figure 6. This last stage is the most important since it gives us additional information on the particular drawing characteristics of Garcia Fernandes. These characteristics are very important to define the painter's work and to compare it to other works attributed to the artist. One of Garcia Fernandes main characteristics is the marking of bones and muscles in the construction of the figures, as we can see as an example in the painting St. Catherine imprisonment by the Emperor. In this painting it is possible to observe some abandoned drawing notes such as the one in St. Catherine's back (Figure $6 a$ ) and also some repositioning of the figures, such as the soldier's leg that was abandoned (Figure 6b). Scale adjustments are also evident, as in the soldier's feet (Figure $6 c$ ); and DD and ID marked with precision and detail, as in the background of angels in the same painting. Marking of shadow areas with thicker parallel lines in ID are observable in all the paintings, being one of the most important individualizing characteristic of the painter, such as the example of the saint's body in The deposition of St Catherine by angels on Mount Sinai. Also in this painting are visible changes to initial drawing, like the repositioning of the head and eyes of the angels holding the saint's body (Figure 7), evidencing an autonomy of the artist concerning the initial thought of the drawing and its intentional deviation, being most probably the master itself to make it [47].

The change of a sketch has its most evident example in the painting of St. Catherine represented as Princess of Alexandria. In the background of this painting a complete theme was abandoned. The scene represents most probably Eve in the Paradise, since it was drawn the bust of a naked woman next to a tree with a serpent (Figure 8). The abandonment of another scene also happened in the painting St. Catherine survival of death by a spiked wheel with the representation of a male figure with a hat (Figure 8). Some figures are found painted without previous drawing, probably as a result of a direct execution during the painting stage. It is also possible to detect same molds in different scales and iconographic changes, such as the saint's crown that was drawn but not painted in the background of the painting St. Catherine represented as Princess of Alexandria (Figure 8).
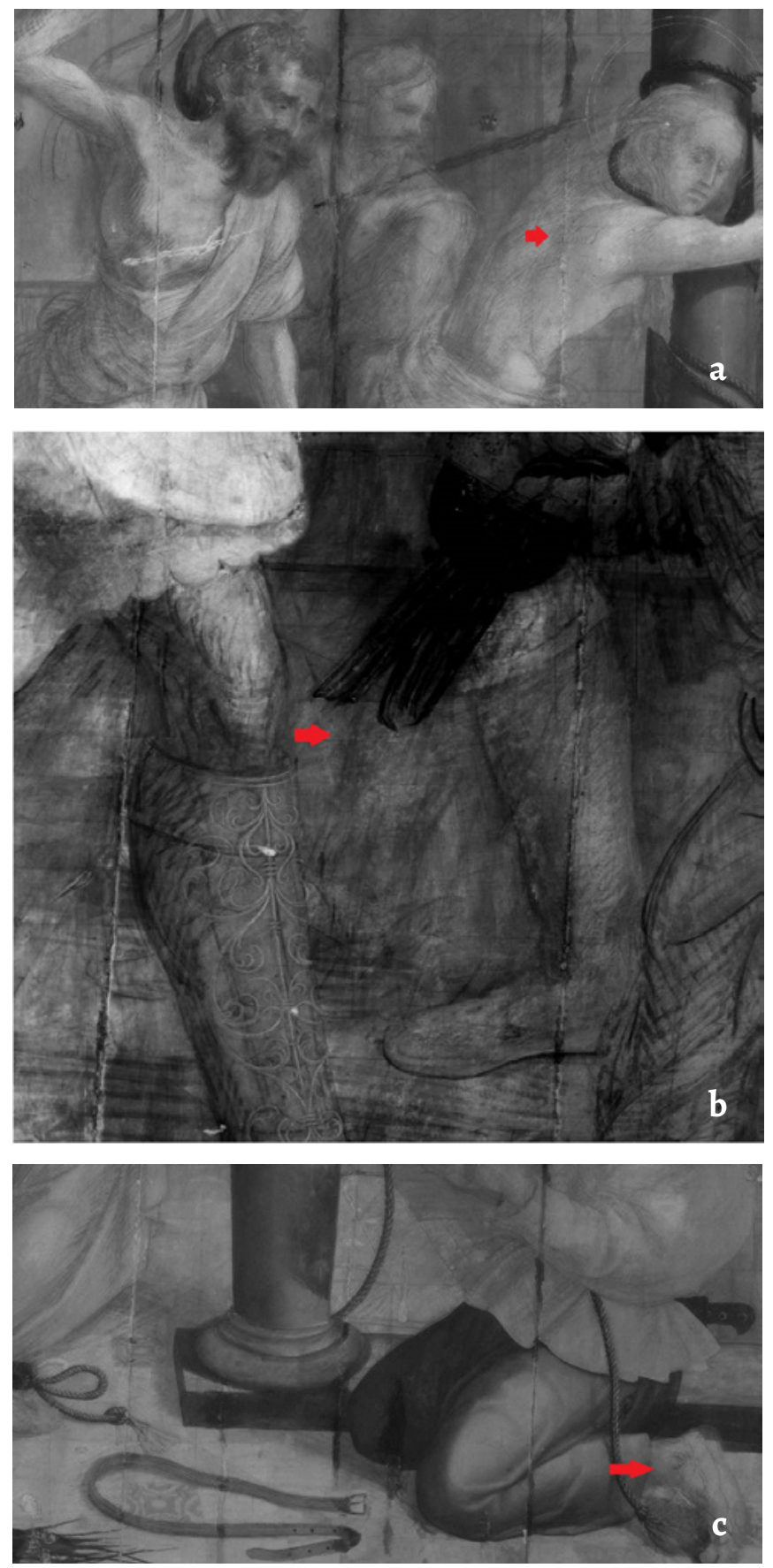

Figure 6. Infrared reflectographies details of St Catherine imprisonment by the Emperor, Goa Cathedral, showing with red arrows: a) abandoned drawing notes in St. Catherine's back; $b$ ) abandoned drawing of soldier's right leg; $c$ ) scale adjustment in the soldier's feet.

\section{Underdrawing comparison among Garcia Fernandes paintings}

The characterization of the underdrawing of the Goan altarpiece allowed defining and comparing the drawing stages with other works of the painter Garcia Fernandes. The three stages of drawing found in Goa Cathedral former altarpiece are possible to be seen in the other studied paintings attributed to the artist, although collaborative works show a simpler drawing with small alterations to the original sketch and some color indications, typical of 


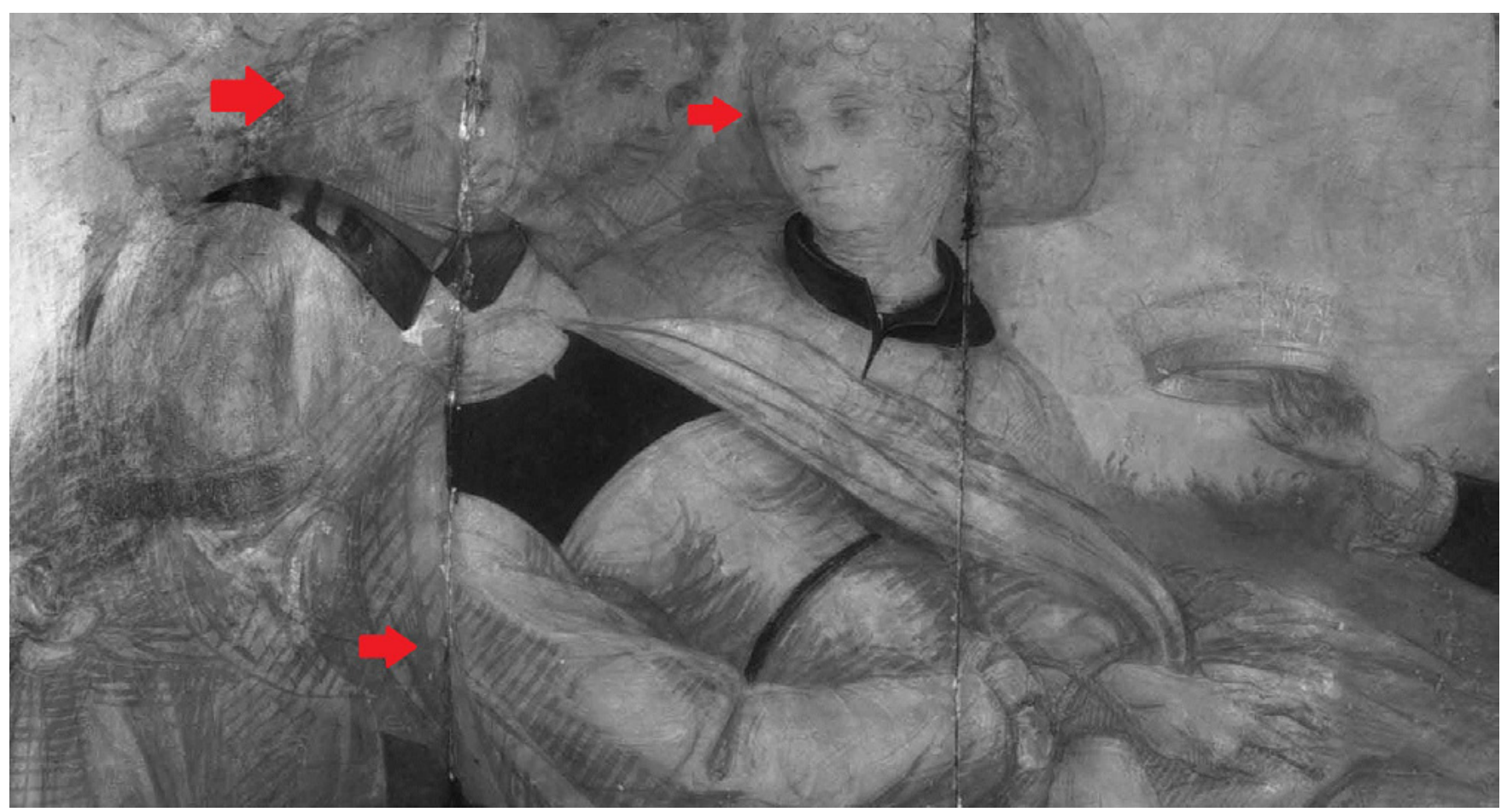

Figure 7. Infrared reflectography detail of The deposition of St Catherine by angels on Mount Sinai where marking of shadow areas with thicker parallel lines in ink drawing and repositioning of the head and eyes of the angels are observable (red arrows).
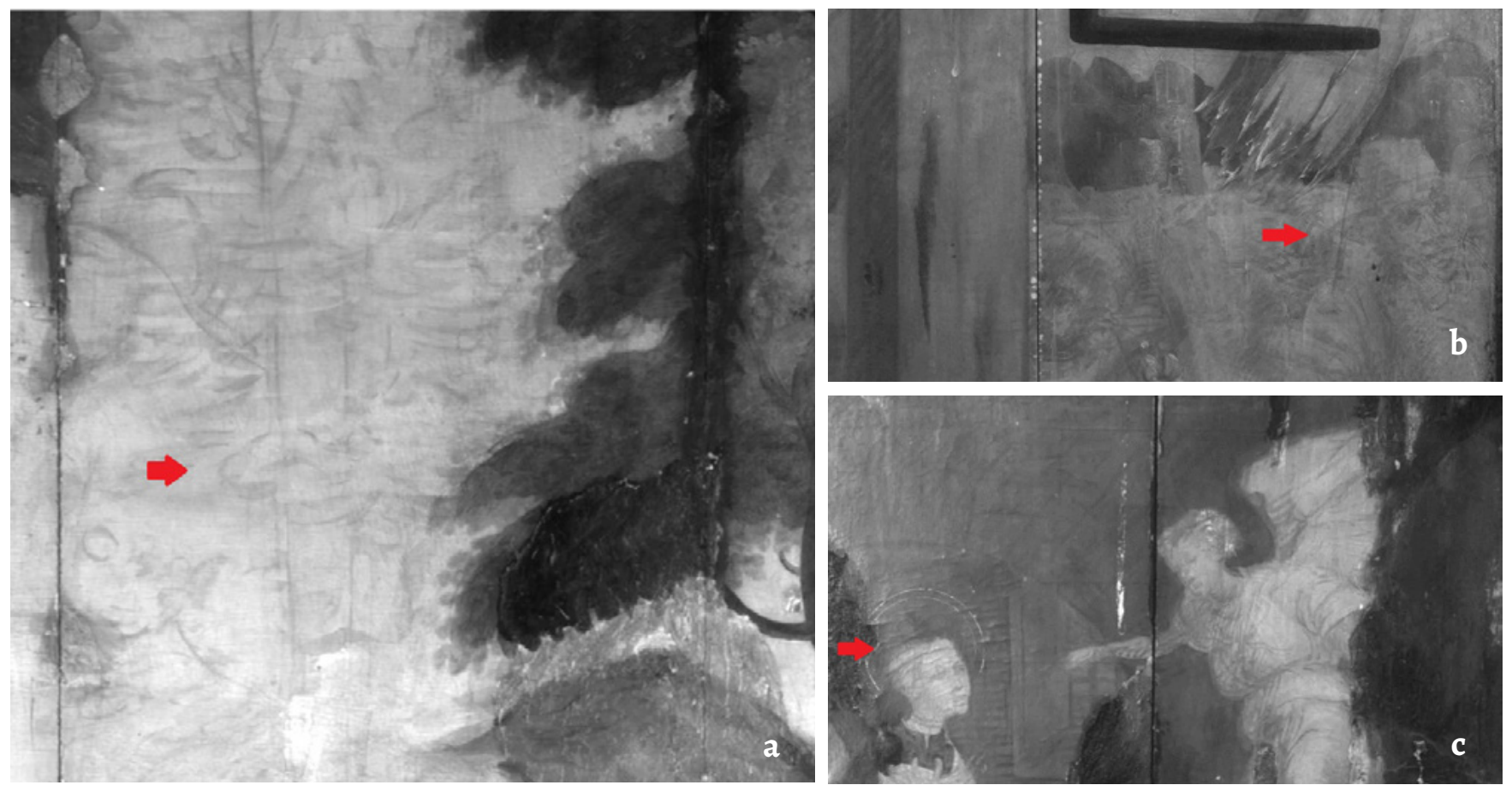

Figure 8. Infrared reflectographies details of: a) St. Catherine represented as Princess of Alexandria, having as abandoned drawing in the background of this painting a scene representing most probably Eve in the Paradise with the snake in the tree (red arrow); $b$ ) abandoned drawing of a male figure with a hat represented in the painting St. Catherine survival of death by a spiked wheel (red arrow); c) iconographic changes of the saint's crown that was drawn but not painted in the background of the painting St. Catherine represented as Princess of Alexandria (red arrow).

workshop production and collaborative work between artists or masters and apprentices [11, 17-18].

Marking of bones and muscles, transpositions of drawing with the help of a card and changes to the initial drawing are possible to find in the Triptych of Piedade, Vila Viçosa
Palace, attributed to Garcia Fernandes (Figure 9a). The use of the same models of angels in different paintings such as the Goan St. Catherine survival of death by a spiked wheel and Nativity, dating from 1537, attributed to Garcia Fernandes, MNAA. In this last painting it is also possible to see 

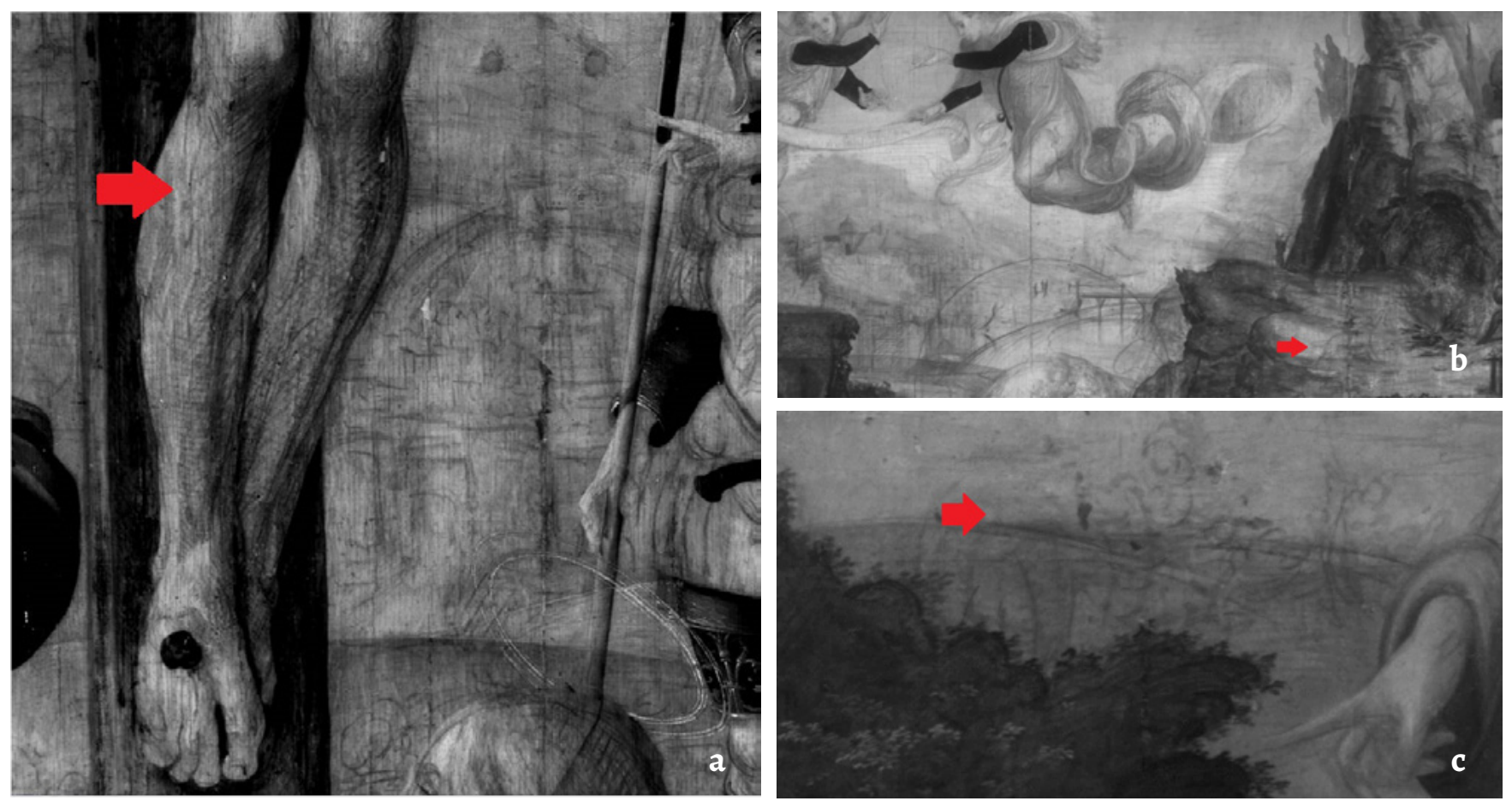

Figure 9. Infrared reflectographies details of: $a$ ) marking of bones and muscles (red arrow), in the Triptych of Piedade, Vila Viçosa Palace; $b$ ) Nativity, MNAA, abandoned drawing, the dog (red arrow); c) Saint Anthony Preaching to the Fishes, MNAA, landscape changes to the initial drawing (red arrow). Credits of $b$ ) and c): Luís Piorro, documents produced under the ONFINARTS Project.
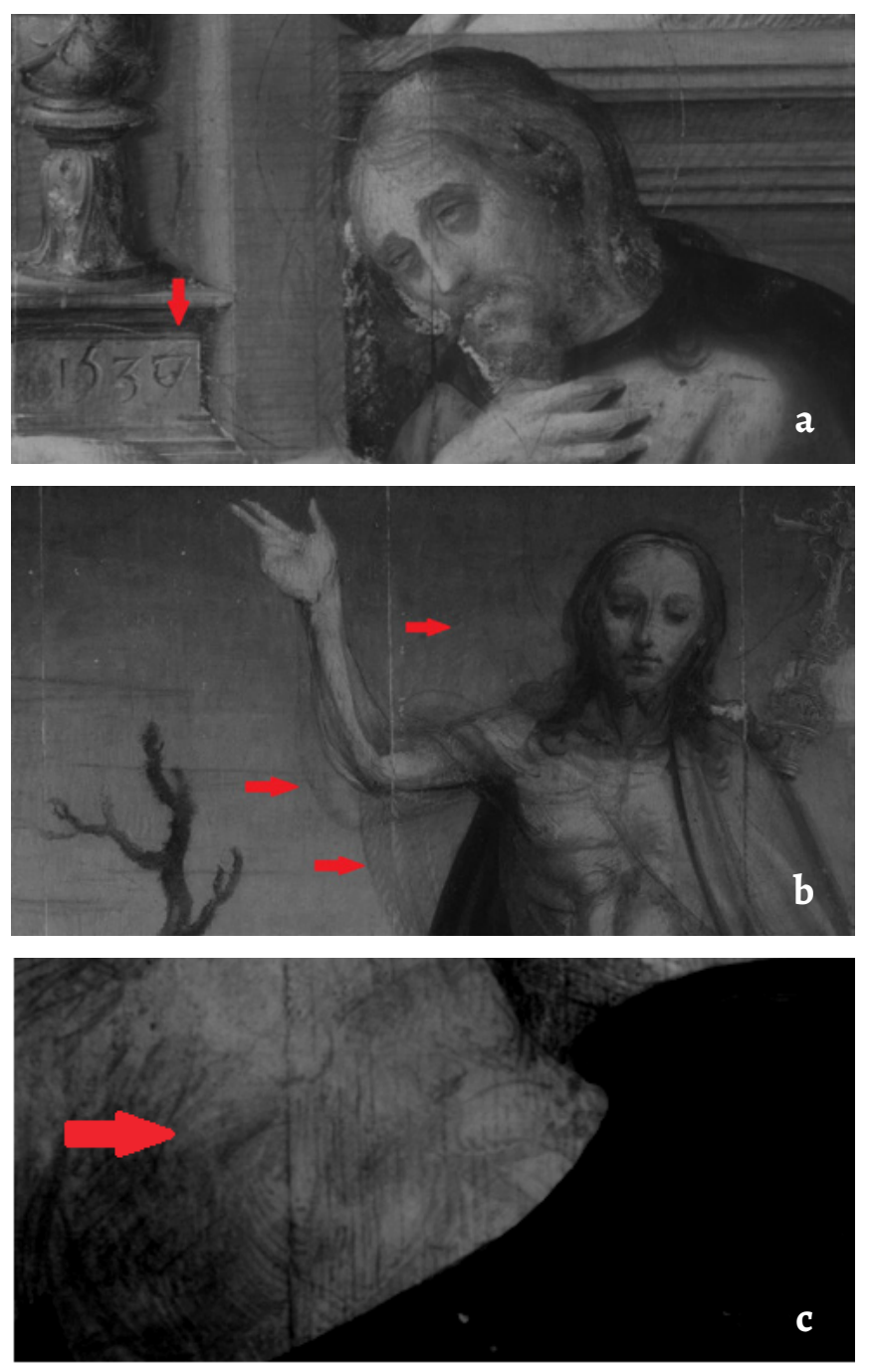

abandoned drawing such as the dog initially drawn in the landscape and discarded at the stage of the painting (Figure 9b). In the painting Saint Anthony Preaching to the Fishes, c. 1535 (MNAA), it is also possible to find architectural and landscape and faces changes to the initial drawing (Figure 9 c). This painting displays similarities to the engraving St Anthony of Padua, surrounded by scenes from his life; of anonymous author, Paduan style, c. 1510-1520 [48]. In the painting Creation of Eve, it is also possible to find scale readjustments in Eve's figure and changes in the landscape background. The final date attribution to the Monastery of the Holy Trinity altarpiece (MNAA) is 1537, although in the reflectography of the Pentecost painting it is possible to observe that the date of 1536 was firstly drawn, and probably changed for working delays or commission demanding (Figure 10a). This painting displays the first GD, showing also changes in the eyes of the apostle to the right, finding the shadow areas with thicker parallel lines in ID and rescaling of the heads. In the painting Resurrection of Christ of the same altarpiece the reposition of Christ's head and abandoned drawing found the mantle, that firstly covered both shoulders, following its inspirational engravings, such as the unidentified publication of a book-illustration

Figure 10. Infrared reflectographies details of: a) Monastery of the Holy Trinity altarpiece (MNAA), the date 1536 behind 1537 (red arrow); b) Resurrection of Christ of the same altarpiece, with the reposition of Christ's head and arm, and abandoned drawing (red arrows); c) the same painting showing the arm of the left soldier (red arrow). Photo credits: Luís Piorro, documents produced under the ONFINARTS Project. 

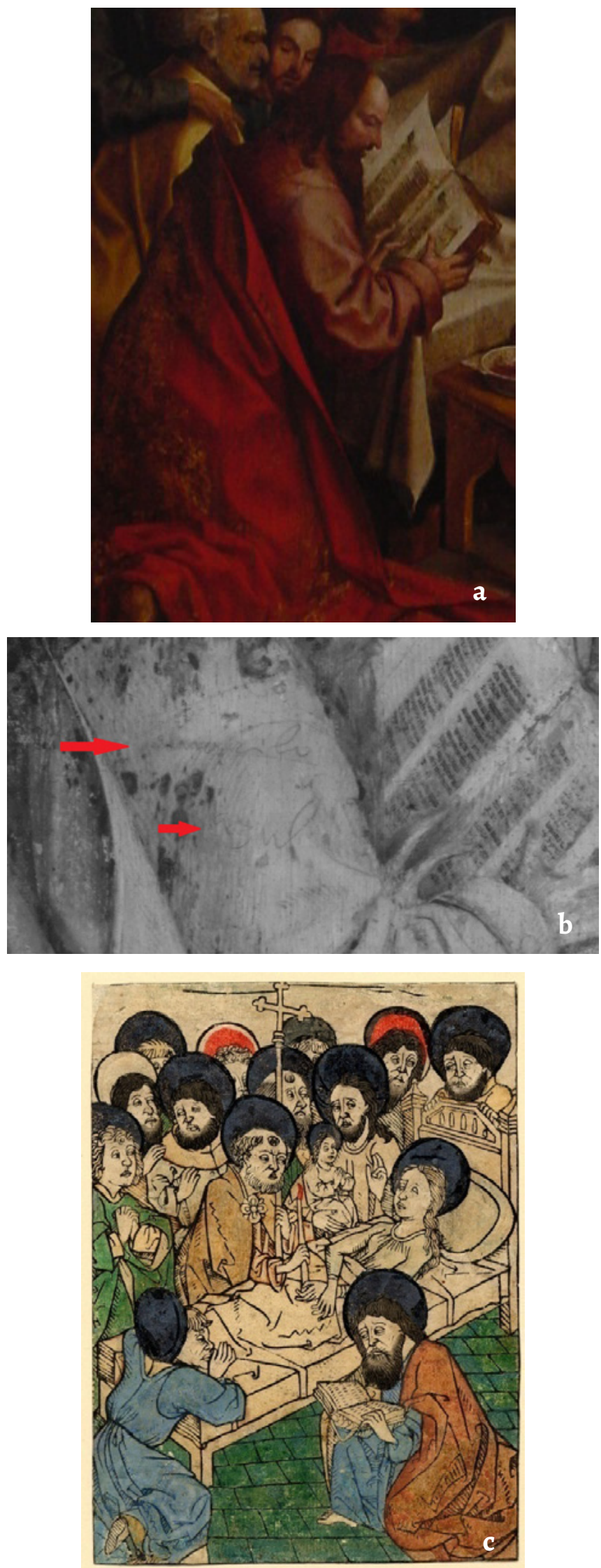

Figure 11. a) Death of the Virgin, detail, a partnership of Ferreirim Masters (MNGV, Arterestauro, 2006); b) infrared reflectography detail of the same painting, written "Amarilo" and "azul" (red arrows) (credits: Luís Piorro, documents produced under the ONFINARTS Project); $c$ ) painting of the same saint fabrics in yellow and blue colors print of woodcut of The Death of the Virgin, of anonymous German artist, circa 1450-1500 (The trustees of the British Museum). made by Hans Wechtlin in 1508 [49], idea abandoned at the stage of the painting (Figure 10b). It is also possible to find the previous geometric drawing marks of positioning, the drawing of bones and muscles, the redrawing of some elements in the figures, such as the feathers in the soldier's hat, changes in the landscape and architectonic background and foreground or in the arm of the left soldier firstly thought as an armor with a brutesque figure (Figure 10c).

\section{Underdrawing of collaborative works}

The same models and repositioning of faces are specifically noticeable in the painting Lamentation from the Altarpiece of S.Bartolomeu, at Lisbon Cathedral. Although this altarpiece is considered as a collaborative work with other painters, this Lamentation underdrawing can be attributed to Garcia Fernandes. In the Adoration of the Magi and Birth of the Virgin, attributed to Garcia Fernandes, 1520-1530, from António Trindade Collection, where similarities with an engraving under the same theme, made by Hans Wechtlin in 1508 are found [50], it is possible to see indications of colors in the fabrics such as "Garaz" in the first painting, probable meaning for madder, and in the second painting "Amarello, Verde, Vermelho(?)", most probably Yellow, Green, Red(?). These indications of color are typical of collaborative work, such as in the painting Death of the Virgin, a partnership of the Masters of Lisbon workshop, also called Ferreirim Masters, Cristóvão de Figueiredo, Gregório Lopes and Garcia Fernandes, where besides the "bco" (white), are also written "amarilo" and "azul" (yellow and blue) in the fabrics of one of the apostles, colors that were not used in the final painting, contrary to former engravings under the same theme that painted the saint fabrics in yellow and blue colors, such as the An example of the woodcut of The Death of the Virgin, of anonymous German artist, c. 1450-1500 (Figure 11) [51]. In this painting it is also possible to identify some changes in the position and form of the objects placed over the table, such as the knife, that was repositioned or the changes in the vase. In the case of the works attributed to Gregório Lopes it is even possible to find the total covering by the artist of painted figures, as it happens with the painting Pentecost (MNAA, cat 27) where an entire figure of an apostle was covered by architectural background, since it was diminishing the Virgin's importance, being initially placed in front of her.

The first work attributed to the Masters of Ferreirim was the altarpiece of the Church of the Convent of Santo António de Ferreirim. Reflectograms allow us to see a simpler and fainted drawing with the careful delineation of outlines, some appearing to be made by card contour and the slight marking of shadow areas, bones and muscles (Figure 12). Fainted drawing can be the result of a material (e.g. ferrogalic ink) used for the execution of the drawing that makes it invisible or barely visible when analyzed through IRR [7].

A concise drawing is also found in other apostle heads belonging to a former predella, nowadays in MNMC (inv. 2536; P526), painted c. 1525-1550 [52]. 


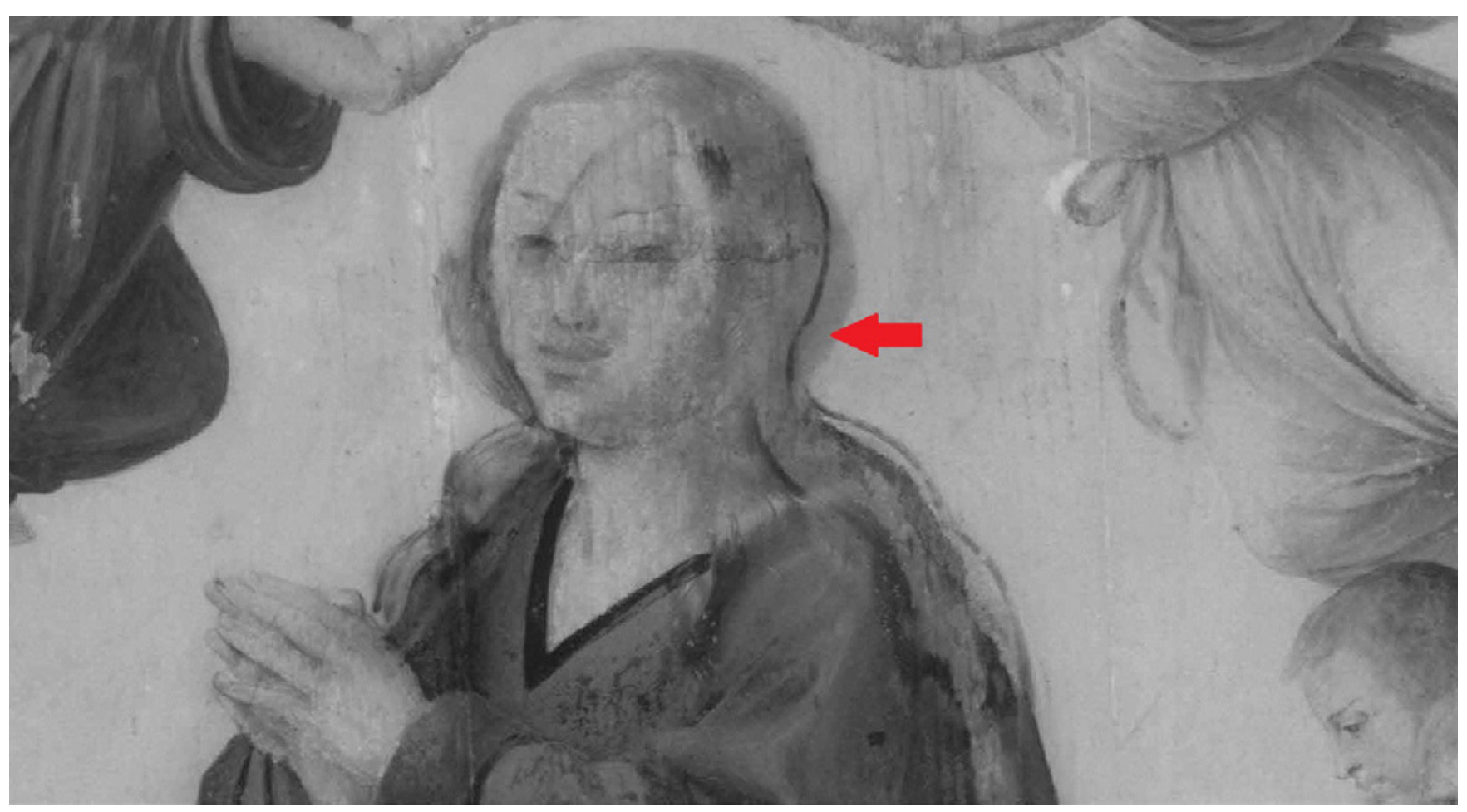

Figure 12. Infrared reflectography detail of altarpiece of the Church of the Convent of Santo António de Ferreirim, Masters of Ferreirim showing the outlines (red arrow). Photo credits: Luís Piorro, documents produced under the ONFINARTS Project.

\section{Conclusions}

What does this mean in terms of the collaborative process? The simpler methods of collaborative works adopted contribute to individualize the stylistic characteristics of the drawing of the Masters considering their own individual works. An adaptation to a simpler organization at the technical level of these masters is observable when working together. All the paintings in Ferreirim altarpiece have similar characteristics at the drawing level. Although, in Bartolomeu Joanes altarpiece the underdrawing is variable in quantity and quality between the different paintings, and inside each painting. On the other hand, it is equally important to realize how Gregório Lopes and Cristóvão de Figueiredo worked individually. This will bring a deeper understanding on the hierarchy of collaboration between these three painters. On the other hand, if they always had an adaptation in collaborative works, how did they organize teamwork? Could one perceive in the case of Garcia Fernandes particular influence of its technical and creative process?

In underdrawing of collaborative works, such as the Panel of St. Bartolomeu of the altarpiece of Bartolomeu Joanes of Lisbon Cathedral, we find a concise drawing when compared to the altarpiece of the Holy Trinity, the Triptych of Piedade of Vila Viçosa Palace, or to the Goa Cathedral former altarpiece, which are most probably a result of individual contracts of the painter and, as such, a free drawing sketchbook by Garcia Fernandes (Figure 13).
Iconographic and stylistic study on Goa Cathedral former altarpiece show south and northern-European influences of former engravings that also inspired the Collaerts, family of antuerpian engravers.

Underdrawing study of Garcia Fernandes Goan altarpiece was defined by the use of a first stage of geometric drawing, a second stage of dry drawing and a third stage of ink fluid carbon drawing, reinforcing the previous stages and defining shadow areas. Two of the main characteristics of Garcia Fernandes drawing are the marking of the shadow areas in thicker parallel lines by liquid medium and the marking of bones and muscles in the construction of the figures. Other characteristics are found in the artist's paintings: geometric drawing of backgrounds and anatomical construction marking, precision and detailed dry drawing, precision and detailed liquid drawing, the use of the same models in different contracts, the use of same mold in different paintings, drawing notes, scale readjustments, abandoned themes, figures and backgrounds, iconographic alterations and painting without previous drawing show an creative autonomy of this artist concerning individual works.

Collaborative works evidence a synthetic and more rigid drawing, using color indications, the use of transposition techniques of the drawing and less quantity of redrawing and rescaling of the figures. These and other information on the painting techniques of each artist may clarify the doubts regarding the organization of the work in collaborative 

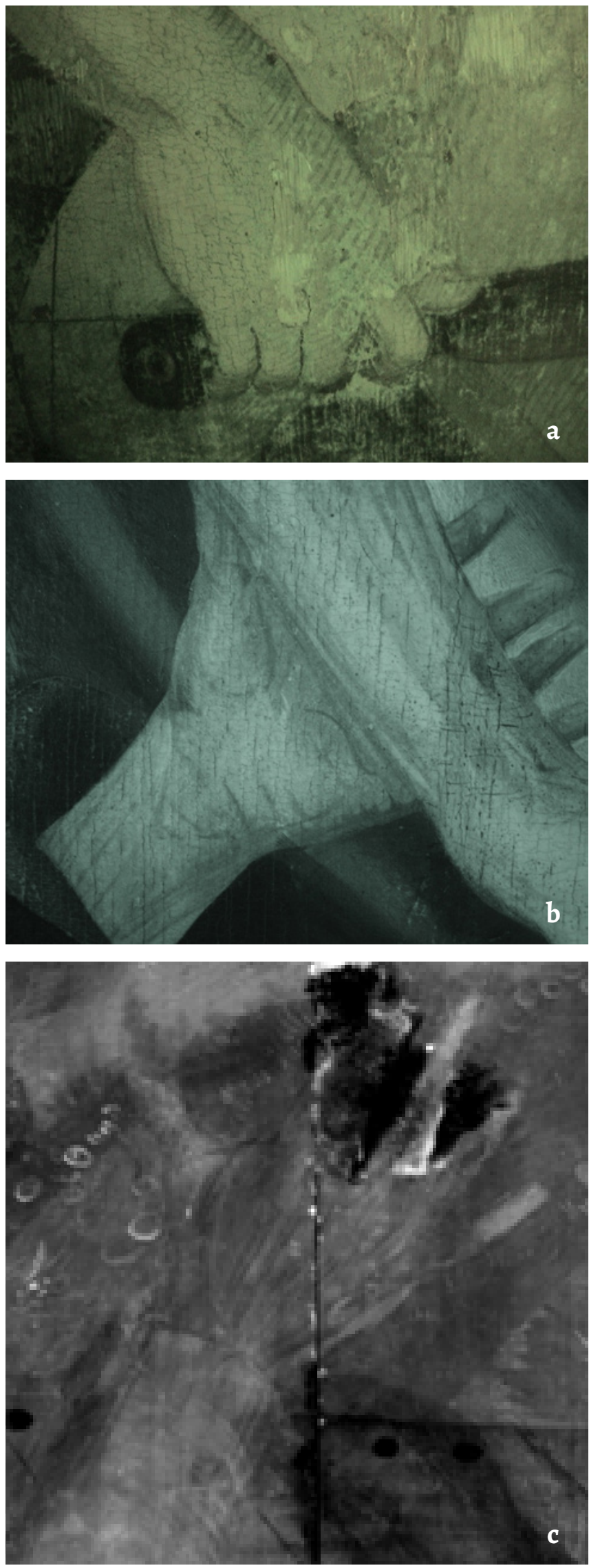

Figure 13. Infrared reflectographies details of: a) panel of St. Bartolomeu of the altarpiece of Bartolomeu Joanes of Lisbon Cathedral with a concise drawing of a hand (credits: Frederico Henriques, Arterestauro, Lda.); b) Triptych of the Piedade of Vila Viçosa Palace; c) Goa Cathedral former altarpiece. In $b$ ) and c) the drawing of bones and muscles in a hand are evidenced. process. Future scientific investigations can further add relevant information to answer remaining questions.

Through the study of Goa Cathedral former altarpiece it was possible to define the work of Garcia Fernandes as a master of drawing, showing the vitality of a continuous state of creation achieved by the artist by drawing its panels as a sketchbook to be painted.

\section{Acknowledgments}

The authors acknowledge to Most Rev. Filipe Neri Ferrão, Archbishop of Goa and Daman, to Fr. Joaquim Loiola Pereira and to Fr. Alfred Vas for allowing this study. Also we wish to acknowledge to Fundação Calouste Gulbenkian for financial support trough the project "De artibus in auream Goa" and Fundação para a Ciência e Tecnologia for financial support (Post-doc grant SFRH/BPD/103315/2014) through program QRENPOPH-typology 4.1., co-participated by the Social European Fund (FSE) and MCTES National Fund. Also acknowledge Natasha Fernandes and Museum of Christian art (MOCA), Mónica Reis and José Pestana, for the assistance in the project. This work was supported by the research center grant no. UID/FIS/04559/2013 to LIBPhys-UNL, from the FCT/MCTES/ PIDDAC and research center grant no. UID/Multi/04449/2013 to Hercules Laboratory. Also acknowledge to Project ONfinearts, LJF, MNAA, MNSR, MNMC, MNGV, Palácio de Vila Viçosa and Mosteiro de Ferreirim. We wish to acknowledge also to Arterestauro, Lda., Luís Piorro, Virgínia Gomes and Frederico Henriques.

\section{REFERENCES}

1. Serrão, V., 'Pintura e devoção em Goa no tempo dos Filipes: 0 mosteiro de Santa Mónica no "Monte Santo" (c. 1606 -1639) e os seus artistas'. Oriente 20 (2011) 11-50.

2. Baptista Pereira, F. A., 'A pintura num período de transição', in História da Arte em Portugal - O Renascimento, ed. D. Markl, Alfa, Lisboa (1986) 83-155.

3. Reis Santos, L., Garcia Fernandes, Artis: Lisboa (1957).

4. Caetano, J. O.; Garcia Fernandes, in Francisco Henriques: um pintor em Évora no tempo de D. Manuel I, ed. A. C. Gouveia, F. A. B. Pereira, Comissão Nacional para as Comemorações dos Descobrimentos Portugueses (1997) 212-215.

5. Antunes, V.; Candeias, A.; Mirão, J.; Carvalho, M. L.; Serrão, V.; Dias, C. B.; Manhita, A.; Reis, M. E.; Manso, M., 'Preserving European paintings in Asian environment. The case of Goa Cathedral former altarpiece', Structural Integrity Procedia 5 (2017) 1078-1085, https://doi.org/10.1016/j.prostr.2017.07.081.

6. Antunes, V.; Candeias, A.; Mirão, J.; Carvalho, M. L.; Serrão, V.; Dias, C. B.; Manhita, A.; Cardoso, A.; Manso, M., 'On the origin of Goa Cathedral former altarpiece: Material and technical assessment to the work of Garcia Fernandes, Portuguese painter from 16th century Lisbon workshop', Microchemical Journal 138 (2018) 226-237, https://doi. org/10.1016/j.microc.2018.01.018.

7. Valadas, S.; Freire, R.; Cardoso, A.; Mirão, J.; Vandenabeele, P.; Caetano, J. O.; Candeias, A. 'New insight on the underdrawing of 16th Flemish-Portuguese easel paintings by combined surface analysis and microanalytical techniques', Micron $\mathbf{8 5}$ (2016) 15-25, https://doi.org/10.1016/j.micron.2016.03.004. 
8. Van Asperen De Boer, J. R. J., 'Infrared Reflectography: a Method for the Examination of Paintings', Applied Optics 7(9) (1968) 1711-1714. http://doi.org/10.1364/ao.7.001711.

9. Musées Royaux Des Beaux-Arts De Belgique, The Flemish primitives: catalogue of early Netherlandish painting in the Royal Museums of Fine Arts of Belgium, Brepols (2009).

10. Billinge, R.; Campbell, L.; Dunkerton, J.; Foister, S.; Kirby, J.; Pilc, J.; Roy, A.; Spring, M.; White, R., 'Methods and Materials of Northern European Painting in the National Gallery, 14001550', National Gallery Technical Bulletin 18 (1997) 6-55.

11. National, G.; Campbell, L., The Fifteenth Century Netherlandish Schools, National Gallery Publications, London (1998).

12. Caetano, J. O., 'Garcia Fernandes. Uma exposição à procura de um pintor', in Garcia Fernandes - um pintor do renascimento. Eleitor de Misericórdia de Lisboa, ed. J. O. Caetano, Santa Casa da Misericórdia, Museu de São Roque, Lisboa (1998) 11-77.

13. Carvalho, J. A. S., 'Oficinas de Lisboa. Garcia Fernandes', in Cores, figura e luz. Pintura portuguesa do século XVI na colecção do Museu Nacional de Soares dos Reis, ed., Museu Nacional de Soares dos Reis, Porto (2004) 28-35.

14. Reis-Santos, L., 'Base para a identificação do pintor quinhentista Garcia Fernandes', Diário de Notícias August 18 (1955).

15. Reis-Santos, L., Estudos de pintura antiga, ed. Reis-Santos, Lisboa (1943).

16. Serrão, V., 'Garcia Fernandes', in No tempo das Feitorias - A Arte Portuguesa na Época dos Descobrimentos II (1992) 142-148.

17. Caetano, J. O., 'Mestres luso-flamengos em Évora - A pintura e o desenho', in Primitivos portugueses, 1450-1550: o século de Nuno Gonçalves, ed. J. A. S. Carvalho, Museu Nacional de Arte Antiga \& Athena, Lisboa (2010) 276-293.

18. Caetano, J. O., 'Lisboa, a grande oficina', in Primitivos portugueses, 1450-1550: o século de Nuno Gonçalves, ed. J. A. S. Carvalho, Museu Nacional de Arte Antiga \& Athena, Lisboa (2010) 200-227.

19. Batoréo, M.; Serrão, V., 'O Retábulo de São Bartolomeu da Sé de Lisboa. Garcia Fernandes numa obra de Parceria', in Garcia Fernandes- um pintor do renascimento. Eleitor de Misericórdia de Lisboa, ed. J. O. Caetano, Santa Casa da Misericórdia, Museu de São Roque, Lisboa (1998) 87-103.

20. Caetano, J. O., O Retábulo de São Bartolomeu da Sé de Lisboa. Garcia Fernandes numa obra de Parceria. Santa Casa da Misericórdia, Museu de São Roque, Lisboa (1998).

21. Caetano, J. O., 'Jorge Afonso, uma interrogação essencial na pintura primitiva portuguesa', $\mathrm{PhD}$ dissertation, Universidade de Évora, Évora (2013).

22. The Beheading of Saint Catherine of Alexandria, https:// www.britishmuseum.org/collectionimages/ANo0554/ ANo0554348_001_l.jpg (accessed 2018-07-21).

23. The Beheading of Saint Catherine of Alexandria, https:// www.britishmuseum.org/collectionimages/ANo0059/ ANo0059259_001_l.jpg (accessed 2018-07-21).

24. The Beheading of Saint Catherine of Alexandria, http:// www.britishmuseum.org/collectionimages/ANo0071/ ANo0071525_001_l.jpg (accessed 2018-07-21).

25. The Martyrdom of St Catherine, https://www.britishmuseum. org/collectionimages/AN01250/AN01250943_001_l.jpg (accessed 2018-07-23).
26. 'Monogrammist IE', in The Trustees of the British Museum, https://www.britishmuseum.org/research/search_the_ collection_database/term_details.aspx?bioId $=47650$ (accessed 2018-2-2).

27. 'Aubert le Mire', in The Trustees of the British Museum, https://www.britishmuseum.org/research/search_the collection_database/term_details.aspx?bioId=23058 (accessed 2018-2-3).

28. Aikin, J.; Enfield, W.; Morgan, T.; Johnston, W., General Biography: Or, Lives, Critical and Historical, of the Most Eminent Persons of All Ages, Countries, Conditions, and Professions, Arranged According to Alphabetical Order. G. G. and J. Robinson (1808).

29. St Catherine Disputing with Fifty Philosophers, https:// www.britishmuseum.org/collectionimages/ANo0459/ ANo0459900_001_l.jpg (accessed 2018-07-23).

30. St Catherine Being Tortured, https://www.britishmuseum. org/collectionimages/ANo0459/AN00459902_001_l.jpg (accessed 2018-07-23).

31. The Queen and Porphyrius Converted by St Catherine, https://www.britishmuseum.org/collectionimages/ANo0459/ ANo0459910_001_l.jpg (accessed 2018-07-23).

32. The Beheading of the Queen and Porphyrius, https:// www.britishmuseum.org/collectionimages/ANo0459/ AN00459909_001_l.jpg (accessed 2018-07-23).

33. The Life of St. Catherine of Alexandria, https://www. britishmuseum.org/collectionimages/ANoO459/ AN00459907_001_l.jpg (accessed 2018-07-23).

34. The Deposition of St Catherine by Angels on Mount Sinai, https://www.britishmuseum.org/collectionimages/ANo0459/ AN00459986_001_l.jpg (accessed 2018-07-23).

35. La Vita Di Caterina Vergine and Martire, https:// www.britishmuseum.org/collectionimages/ANo0453/ ANo0453134_001_l.jpg (accessed 2018-07-23).

36. Deposizione Di Santa Caterina D'alessandria Nel Sepolcro, http://www.lombardiabeniculturali.it/stampe/schede/Co11o00337/ (accessed 2018-07-23).

37. The Burial of St Catherine, http://www.britishmuseum.org/ collectionimages/ANoO430/ANo0430257_001_l.jpg (accessed 2018-07-23).

38. The Burial of St Catherine, http://www.britishmuseum.org/ collectionimages/ANo0225/ANo0225937_001_l.jpg (accessed 2018-07-23).

39. The Burial of St Catherine, https://www.antichitacastelbarco. it/it/prodotto/scuola-veneziana--500---bottega-di-jacopotintoretto- (accessed 2018-07-23).

40. St Catherine as a Martyr, https://www.britishmuseum.org/ collectionimages/ANo0459/AN00459892_001_l.jpg (accessed 2018-07-23).

41. St Catherine as a Martyr, https://www.britishmuseum.org/ collectionimages/ANo0046/ANo0046743_001_l.jpg (accessed 2018-07-23).

42. Creation of Eve, http://www.britishmuseum.org/ collectionimages/ANo0068/ANo0068238_001_l.jpg (accessed 2018-07-23).

43. Transfiguratio Domini Nostri Iesu Christi, http:// www.britishmuseum.org/collectionimages/AN00906/ AN00906498_001_l.jpg (accessed 2018-07-23). 
An Artist's Sketchbook: the former altarpiece of Goa Cathedral (India) attributed to the painter Garcia Fernandes

44. The Last Judgement, http://www.britishmuseum.org/ collectionimages/AN00073/AN00073189_001_l.jpg (accessed 2018-07-23).

45. Christ Enthroned, http://www.britishmuseum.org/ collectionimages/ANo0544/AN00544838_001_l.jpg (accessed 2018-07-23).

46. The Assumption of the Virgin, http://www.britishmuseum. org/collectionimages/ANo0045/ANo0045867_001_l.jpg (accessed 2018-07-23).

47. Metzger, C.; Berrie, B., 'Gerard David's St. Anne Altarpiece: Evidence for Workshop Participation', in Historical Painting Techniques, Materials, and Studio Practice: Preprints of a Symposium, ed. A. Wallert, E. Hermens, M. Peek, Getty Conservation Institute, USA (1995) 127-134.

48. St Anthony of Padua Surrounded by Scenes from His Life, http://www.britishmuseum.org/collectionimages/ANoo037/ AN00037749_001_l.jpg (accessed 2018-07-23).

49. Resurrection of Christ, http://www.britishmuseum.org/ collectionimages/AN00565/ANo0565071_001_l.jpg (accessed 2018-07-23).

50. Birth of the Virgin, http://www.britishmuseum.org/ collectionimages/AN00565/AN00565058_001_l.jpg (accessed 2018-07-23).

51. The Death of the Virgin, http://www.britishmuseum.org/ collectionimages/AN00042/AN00042867_001_l.jpg (accessed 2018-07-23).

52. Antunes, V., 'Técnicas e materiais de preparação na pintura portuguesa dos séculos XV e XVI', PhD dissertation, Universidade de Lisboa, Lisboa (2014).
RECEIVED: 2018.12 .9

REVISED: 2019.6 .19

ACCEPTED: 2019.6.27

ONLINE: 2020.7.31

\section{(1) (1) $(9$}

This work is licensed under the Creative Commons Attribution-NonCommercial-NoDerivatives 4.0 International License. To view a copy of this license, visit

http://creativecommons.org/licenses/by-nc-nd/4.o/deed.en. 